\title{
The Contentious American Debate: The First Amendment and Internet-based Hate Speech
}

\author{
PAUL J BECKER, BRYAN BYERS and ARTHUR JIPSON ${ }^{1}$
}

\begin{abstract}
This essay reviews the debate over what constitutes hate speech and whether or not such speech is protected by the American First Amendment. First, the concept of white racialism and white supremacy is defined and illustrated. Then after a brief discussion of the legal debate, the nature and problematic definition(s) of hate speech is presented. The unique speech environment of the internet is reviewed alongside attempts to limit and censor topics available on the internet. The arguments for and against restricting first amendment protection are discussed, with a focus on Michael lsrael's five criteria for withdrawing first amendment protections. ${ }^{2}$ The work concludes with a discussion of the difficulty in constraining discourse on the internet.
\end{abstract}

\section{Introduction}

Hate speech remains the Pandora's box in American legal debates. The problematic issue began at the time of the founding of the American system of government with the fiery debates, between the Federalists and anti-federalists, over the role of the federal government, state's rights, and individual rights. The resolution to the political dilemma of balancing these three different constituencies led to the landmark achievement of the Bill of Rights in 1787. Those 10 initial amendments to the American Constitution established the protections which individuals and the state could expect from federal governmental authority. The drafters of the First Amendment, which was adopted in 1791, wrote it in broad, nearly absolute strokes:

Congress shall make no law respecting an establishment of religion, or probibiting the free exercise thereof; or abridging the freedom of speech, or of the press; or the right of the people peaceably to assemble, and to petition the government for a redress of grievances. (Our emphasis.)

Debates have raged over what is protected speech, or speech free of governmental interference; though hate speech did not become an issue until the 1920 s and 'meaningful'

Paul J Becker, Morehead State University; Bryan Byers, Ball State University; Arthur Jipson, Miami University of Obio. Correspondence: Bryan Byers, Department of Criminal Justice and Criminology, Ball State University, Muncie, Indiana, USA;e-mail<bbyers@bsu.edu>. 
protection of free speech did not occur until a decade or two later. ${ }^{3}$ This paper will examine First Amendment issues as they apply to racialist and hate speech on the internet, beginning with defining white racialism.

\section{Defining Terms}

White racialism is an umbrella term that includes the widely divergent types of racist social movements and individual racist activities. The term originated among adherents in contemporary white supremacist discourse as a more adequate label for racist activity because it does not limit the individual or group to one particular theme or view. Given the wide variation in so-called white supremacists, the term racialism is much more inclusive of the variety of factions that exist within the broader context of what is labelled white supremacy. What is usually referred to as white supremacy often includes skinheads, members of different factions of the Ku Klux Klan, Christian Identity adherents, national socialists, white separatists, and white survivalists. All of these types of beliefs and activities are discrete forms of white racialism. They each possess unique beliefs, values and organization. To refer to these groups as the same, obscures the real differences between them. Since the term white racialist is self-designated and applied, it is more appropriate than using non-movement interpretations. It is important to note that individuals who engage in hate speech may not be members of a white racialist group. However, many hate-related internet sites are affiliated with racialist organizations. If we, as a society, are to better understand extremism, then we must seriously review and comprehend the views of extremists, which in turn will lead to a better understanding where much of the hate speech on the internet comes from. The following section will examine how racialists utilize the internet.

\section{Racialists, Hate Speech and the Internet}

Since the beginning of the modern American white racialist movement, after the Second World War, racialists have used a variety of communicative tools to reach prospective members and racialist social movement actors. From the beginning of the movement, traditional print communication has been used (e.g. flyers, newsprint, posters, leaflets, pamphlets, books) as the dominant form of spreading information to prospective members and comrades-in-arms. Today a variety of additional tools are utilized, including computermediated communication, radio, music, phone lines/messages, videos and cable television programs.

The National Alliance, one of the major distributors of racialist materials in the US, has a lengthy catalogue listing important texts of the movement, such as the Turner Diaries. In addition, actors within the movement have contributed to radio and television talk shows. The leader of the National Alliance, William Pierce, hosts 'American Dissident Voices' a short-wave radio program and Tom Metzger of White Aryan Resistance hosts the racialist cable-access program, 'Race and Reason'. However, it is the internet that provides most opportunities today. It is our contention that white racialists use the internet to recruit, disseminate information, organize activities, appeal to the emotion of potential sympathisers, and dramatise their presence. Don Black, who has been connected with the white racialist movement since the 1970 s, made the following statement about the internet: 
All of this has had a pretty profound effect on a movement whose resources are limited ... with the phenomenal growth of the Internet, tens of millions of people have access to our message.... The access is anonymous and there is unlimited ability to communicate with others of a like mind. ${ }^{4}$

One way this technology is utilized is through Usenet newsgroups, which are discussion areas available to anyone with basic access to the internet. These newsgroups (e.g. alt.skinhead and alt.white.nationalism) function as archives of racialist discourse with non-racialists and sympathetic supporters. Commentary of this form is often heated and passionate and is usually dominated by non-racialists. Listserv lists and Bulletin boards are used by racialists as another mechanism of discussion where subscribers alone receive the information. Discussions via these mechanisms tend to stay more focused on the general parameters of the topic and are led by interested parties. On the one hand, Listserv lists (e.g. Storefront, Zgram) represent discussion that is disseminated through a mail deflector, which is located on a particular computer and acts as a distributor (i.e. a server). This server acts as a mail duplication system-spreading the message of a single poster to everyone who has subscribed to the list. A Bulletin board service, on the other hand, is a discussion list that the subscriber has to access electronically, usually through the use of a phone modem.

White racialists regularly use Listserv lists and Bulletin boards as soundboards where they bounce ideas and plans off of each other. Since admittance to these services require subscription of some kind (paid or not), racialists are better able to screen out non-racialists, unlike in the open environment of Usenet. Web sites function in a variety of ways. Where newsgroups, Listserv lists and Bulletin boards are limited in their appearance, organization and activity, web pages allow for a variety of interactions. Web pages bring together all of the functions of the other internet mechanisms because they not only store text information but video, chat and audio communication as well. White racialists regularly use web sites to archive a variety of materials and documents making them available for downloading. Often the materials found on these sites meets someone's definition of hate speech. Questions on defining hate speech will be addressed next.

\section{Questions in Defining Hate Speech}

Hate speech can be defined a number of ways. Is offensive speech that is directed at minorities because of their race or national origin hate speech? Is the comment or designation 'white trash' a form of hate speech? Is a classic work of literature hate speech if a segment of the population considers it demeaning? Are sexist epithets a form of hate speech? What is deemed hate speech tells more about the way of life in a culture, than a clearly defensible view of appropriate and inappropriate discourse. The debate over what is, or is not, hateful speech is a significant struggle over the very nature of democracy itself. When a form of speech is designated as hate speech, the assertion is made that because of its nature and content, the utterance or idea lacks justification for open discussion and review. Constitutional protection guarantees that even unpopular ideas shall not be stifled by the will of the majority of citizens. However, a 1997 Chicago Tribune poll noted that almost one-third of Americans believe that the First Amendment has been interpreted as going too far in guaranteeing free speech and half of the respondents support government imposed restrictions on internet speech. ${ }^{5}$ 
If attempts are made to limit free speech, who will determine what is hate speech? To illustrate the potential problems with this, another current controversy in the US can be examined-hate crime legislation. Hate crime legislation allows for harsher penalties when victims are chosen based on some characteristic such as race, religion, or disability. If a state decides to enact this type of law, a decision must be made as to which groups are given 'protected' status. The major controversy over this involves sexual orientation. Some people feel that to protect someone based on this characteristic is to condone homosexuality, which they feel is a sin. If attempts are made to restrict 'hateful' speech, it would seem that the same debates would take place with interest groups lobbying to forbid hate speech targeting their group, or lobbying to allow hate speech against groups viewed as being sinful or evil.

Taking all of this into account, the authors contend that in constructing a definition of hate speech, one is really crafting unspoken rules regarding discourse. Based on previous discussions, here is one definition of hate speech. Hate speech is speech that inflicts emotional damage and contains inflammatory comments meant to arouse other individuals to cause severe social dislocation and damage. Such utterances, in their context, are considered devoid of intellectual, philosophical, or scientific merit. The community is not served in any fashion through this discourse. For example, lacking scientific merit can be interpreted to mean that the speech does not increase the community's stock of knowledge in any measurable or discernible manner. In fact, the speech degrades targeted individuals and groups to the extent that they suffer significant and long-standing psychological deleterious consequences or sociological hardship. These comments are not satirical or artistic reflections of society and leave (again) no lasting benefit to the community via critique or alternate interpretation. The US Supreme Court has also wrestled with the issue of defining hate speech. Next, the court's interpretation as to what types of speech are protected by the First Amendment will be outlined.

\section{Hate Speech and the Supreme Court}

Hate speech has been an issue for approximately 70 years and a comprehensive overview is beyond the scope of this paper. ${ }^{6}$ However, the findings in four important First Amendment cases can be ourlined. Chaplinsky v. New Hampshire established the 'fighting words doctrine' when Justice Murphy, of the Supreme Court, defined two exceptions to protected speech: words that (1) 'by their very utterance inflict injury' and (2) 'tend to incite an immediate breach of peace'; though the second exception has since been ruled 'defunct'. In Beauharnais v. Illinois' the court ruled in favour of a law that made it unlawful for anyone 'to manufacture, sell, or offer for sale, advertise, or publish, present or exhibit in any public place ... [anything that] portrays depravity, criminality, unchastity, or lack of virtue of a class of citizens, of any race, colour, creed or religion', when such publications would expose the citizen of any race, colour, creed or religion to contempt, derision, or obloquy or which is productive of breach of the peace or riots' ${ }^{10}$

Another case, Brandenberg v. Obio"1, 'Established the right to advocate offensive racial or religious ideas-including the deportation of African Americans and Jews-as long as this advocacy did not reach the point of direct incitement to riot' ${ }^{12}$ When a Nazi group wanted to march in a predominately Jewish community in Skokie, Illinois, Federal courts ${ }^{13}$ ruled that ordinances prohibiting the march were unconstitutional for several reasons, including they were not violations based on Chaplinsky and Brandenberg. ${ }^{14}$ In answering the question of why hate speech is allowed by the Bill of Rights, Walker states that 'the 
First Amendment itself did not force us to do anything. The First Amendment came to protect hate speech because we choose to interpret it that way.' ${ }^{\text {is }}$ Therefore, the First Amendment to the Constitution of the United States is not easily overcome when addressing the permissibility of hate speech. Hate speech is largely protected by the First Amendment whether on the internet or in other forums. Jacobs and Potter state that since the Chaplinsky decision:

[e]very time a state or local government has sought to use criminal law to punish someone for offensive speech that might provoke violent retaliation, the Court [the US Supreme Court] has ruled against the government and reversed the conviction. ${ }^{16}$

Such judicial precedent presents a formidable obstacle in addressing the potential inflammatory nature of hate speech. The next section examines opposition to restricting hate speech.

\section{Protecting Hate Speech}

One of the many causes taken up by the American Civil Liberties Union (ACLU), in an effort to protect internet-based free speech, is 'Cyber-Civil Liberties'. In one of these cases, a group of plaintiffs sued the Board of Trustees of the Loudoun County (Alexandria, Virginia) Library for restricting patron access to sex-related web sites (Mainstream Loudoun et al. v. Board of Trustees of the Loudoun County Library). The court ruled that the Library did unreasonably restrict access. The decision was lauded by the ACLU as a victory in the protection of Cyber-Civil Liberties. The ACLU has also come out on the side of internet-based hate speech when ACLU President Nadine Strossen teamed with Webmaster Ken McVay of the Nizkor Project, an internet site that counters the claims of Holocaust deniers. ${ }^{17}$ During an address, McVay, along with Strossen, discouraged any censorship of webmasters who might proffer hate propaganda online. ${ }^{18}$ A nother author offers an alternative solution to opposing censorship of hate speech:

It demands listening carefully, thinking rationally, judging critically, and refuring vigorously those ideas and ideologies we find offensive or wrong. Such an approach requires both skill and courage, but the res publica will benefit most from allowing such expression and by a public refutation showing it to be wrong. ${ }^{19}$

While there are opponents to restricting any type of speech, several authors have proposed criteria to revoke First Amendment protection for hate speech.

\section{Revoking First Amendment Protection for Internet Based Hate Speech}

Criteria for revoking First Amendment protection of speech remain a difficult burden. At no time should government try to restrict legitimate First Amendment rights. However, there may be instances in which First Amendment protection is not suitable for some speech. One author, Mari Matsuda, comments that 'Government protection of the Klan to exist publicly and to spread a racist message promotes the role of the Klan as a legitimizer of racism. Further, the law's failure to provide recourse to person's who are demeaned by the hate messages is an effective second injury to that person. ${ }^{20}$ The author suggests criminalizing hate speech with the following characteristics:

1. The message is of racial inferiority 
2. The message is directed against a historically oppressed group

3. The message is persecutory, hateful, and degrading ${ }^{21}$

These standards are problematic in that they would allow hate speech against certain groups, such as homosexuals. This is the very debate alluded too earlier in the discussion on how lobbying would take place to determine what groups deserve protection from hate speech. Another author, Michael Israel, contends that:

Five criteria need to be evaluated, with the burden on the government to convincingly argue that all five have been met to remove First Amendment protection. According to a reasonable person (Criterion 1), does the dominant theme of the material, taken as a whole (Criterion 2), cause injury (Criterion 3 ) without redeeming social value (Criterion 4) under the current facts and circumstances? (Criterion 5). ${ }^{22}$

It should seem obvious that these criteria, as is the case with any legal criteria, seem rather ambiguous. It would be up to a court to determine how reasonable each of the criteria, taken together, would be in order to revoke First Amendment protection. It is worthy to remind the reader that First Amendment revocation in the US is a 'slippery slope' fraught with many difficulties.

As a result, questions need to be posited before employing such criteria. First, how reasonable are each of these components? Taken as a whole, the criteria seem reasonable to revoke First Amendment protection. However, the third criteria of 'injury' might be the most difficult for a court to grapple with. In American justice, the notion of injury can be interpreted in a number of ways. There is the obvious physical injury, which might be inflicted on an individual, while there may also be psychological injury (emotional damage), and injury to one's reputation (libel). Ascertaining these latter types of injury have traditionally been more difficult than determining physical injury. In a word, physical injury is tangible and psychological injury is less tangible. However, protection might still be removed if a jury and court determines that either or borh of these criteria are met. Second, how do these criteria differ in an internet speech situation as compared to other forms of speech? There are many parallels between free speech on the internet and other varieties of free speech. The authors argue that there is little difference at all when comparing the different vehicles for the dissemination of information (i.e. written, verbal, electronic). Perhaps one of the most interesting dilemmas one might encounter is how internet-based information can and cannot be policed, and eventually lose First Amendment protection. Bulletin boards or Listserv lists may be unavailable without knowledge obtained from within the movement, while Web pages may employ passwords and other security provisions to block unwanted entrance. These techniques to block outsider access would make enforcement of First Amendment restrictions difficult to carry out.

Another problem in restricting information on the internet is that people may still be able to access information that is illegal in their country, from a web site hosted in another country. For example, Amazon.com and Barnsandnobel.com have been accused of violating German law by mailing, into that country, copies of Mein Kampf. ${ }^{23}$ There are also mechanisms designed to limited access to 'hate speech' on the internet, without violating the First Amendment. Since the First Amendment only forbids government restrictions of speech, internet service providers (ISP's) may ban certain WebPages, such as those containing hate messages. Another mechanism is for parents, libraries and schools to install filtering devices such as Hate Blocker ${ }^{24}$ or HateFilter ${ }^{25}$ so hate sites cannot be accessed. However, the ultimate decision to employ such methods is up the individual user. So long 
as the information does not incite violence or injury to others, there is little one can do in advocating for the revocation of First Amendment protection. While this discussion has centred on what the authors believe to be two fundamental questions regarding whether internet-based hate speech can be protected under the First Amendment, it is important to revisit the fact that all five criteria, according to Israel, ${ }^{26}$ would have to be met in order to revoke this right. This would undoubtedly be a daunting and laborious task. However, the Anti-Defamation League (ADL), a long time advocate against Anti-Semitism has pointed out instances where internet based hate speech has not been protected. ${ }^{27}$ This type of speech will be discussed next.

\section{Speech not Potected by the First Amendment}

The ADL makes the following point regarding internet based hate speech:

Blanket statements expressing hatred of an ethnic, racial or religious nature are protected by the First Amendment, even if those statements mention individual people and even if they cause distress in those individuals. Similarly, denial of the Holocaust-though abhorrent-is almost never actionable under American law. The Constitution protects the vast majority of extremist Web sites that disseminate racist or anti-Semitic propaganda. ${ }^{28}$

As one might observe from this passage, speech, even if it causes distress to the individual reader, would likely be protected speech. This was pointed out above with regard to Israel's 'injury' criteria ${ }^{29}$ and how difficult psychological distress is to prove. Therefore, offensive internet-based hate speech, in and of itself, would be protected. The ADL goes on to claim that:

Internet speech that is merely critical, annoying, offensive or demeaning enjoys constitutional protection. However, the First Amendment does not provide a shield for libelous speech or copyright infringement, nor does it protect certain speech that threatens or harasses other people. For example, an E-mail or a posting on a Web site that expresses a clear intention or threat by its writer to commit an unlawful act against another specific person is likely to be actionable under criminal law. Persistent or pernicious harassment aimed at a specific individual is not protected if it inflicts or intends to inflict emotional or physical harm. To rise to this level, harassment on the Internet would have to consist of a 'course of conduct' rather than a single isolated instance. A difficulty in enforcing laws against harassment is the ease of anonymous communication on the Internet. Using a service that provides almost-complete anonymity, a bigot may repeatedly E-mail his victim without being readily identified. ${ }^{30}$

While there are clear issues of anonymity on the internet, and the ability for a person to remain unidentifed, there have been cases that demonstrate the two principles outlined above: (1) speech that 'expresses a clear intention or threat by its writer to commit an unlawful act against another specific person' or (2) 'a "course of conduct" rather than a single isolated instance.' Each of these points will be taken in turn, as they apply to Israel's notion of 'injury'.31

First, speech that expresses a clear intent to commit or threaten harm is not protected speech. A well-known case fitting under this category involves the web site "Nuremberg Files'. ${ }^{32}$ This site contained clearly articulated information promoting violence, threats, and atracks against doctors and other health professionals participating in the delivery of 
abortion services. Most notably, there were surveillance photographs of abortion doctors (which included times of movement), home addresses, names and addresses of family members, and license plate numbers. Also included on the site was a 'hit list' of abortion doctors and once a doctor on the list was murdered, the name was marked out with a line. As a result of this site, a group coalition of anti-abortion forces was ordered to pay over $\$ 100$ million in civil penalties for their actions. ${ }^{33}$ While this example involves civil remedy, the following example is one where criminal prosecution was used. Under the second principle, speech which is determined to be a 'course of conduct' promoting threats to health and well being is not worthy of First Amendment protection. At the University of California at Irvine, a student sent over 50 hate-based e-mail messages to Asian students. The message, signed 'Asian Hater', said that he would 'make it my life career [sic] to find and kill everyone one [sic] of you personally'. ${ }^{34}$ The former student received a sentence of one year in prison for these acts.

\section{Conclusion: Can the First Amendment Work in Cyberspace?}

Many questions remain, and surely debates will follow, regarding the limits to free speech in a nearly limitless forum-the internet. However, the utility of the internet for research and the dissemination of information is demonstrated in the growing ubiquity of access and presence in American culture. For racialists, the internet has proven a useful tool for educating members in the core beliefs and ideas of the movement. In addition, this form of communication has demonstrated its power in mobilizing racialists for rallies, speeches and demonstrations. However, just as racialists use the internet, so can those with opposing viewpoints, such as individuals and organisations promoting diversity and anti-hate sentiments. Researchers may also use the internet to access racialist materials allowing society to better understand these groups and individuals. Therefore, there may be some advantages to allowing racialists First Amendment protections.

The types of speech not protected by the First Amendment are based on the Court's interpretation. Any attempts to place restrictions on hate speech, which is currently viewed as being protected, would lead to endless debate and controversy. Six years after the Supreme Court ruled that penalty enhancement hate crime laws are constitutional, their decision is still being evaluated and criticized. With hate speech, there is a double edged sword. If all hate speech is restricted, the groups and individuals promoting this speech will feel infringed upon. If only certain categories of hate speech are restricted, segments of the population may feel devalued by society if they are the targets of hate speech not restricted. Regardless of the potential controversy discussed in this essay, the central argument can be summarized as being an issue of free speech and the reluctance to begin down the "slippery slope' of placing any additional restrictions on hate speech.

\section{Notes and References}

1 NB The authors are listed alphabetically.

2 M Israel 'Hate speech and the First Amendment', Journal of Contemporary Criminal Justice, 1999, Vol 15, No 1, pp 97-110.

3 S Walker Hate Speech: The History of an American Controversy, University of Nebraska Press, Lincoln, 1994.

4 K Schneider 'Hate groups use tools of the electronic trade', New York Times, 13 March 1995, p A12. 
5 C M Madigan and B Secter 'Second thoughts on free speech', Chicago Tribune, 4 July 1997, pp 1, 18-21.

6 See Walker, op. cit.

7 Chaplinsky v. New Hampshire, 315 US 568 (1942).

8 Walker, op. cit., p 115.

9 Beawharnais v. i, 343 US 250 (1952).

10 Walker, op. cit., p 92.

11 Brandenberg v. Obio, 395 US 444 (1969).

12 Walker, op. cit., p 115.

13 Collin v. Smith, 578 F 2d 1197, 1206 (7th Cir. 1978).

14 Walker, op. cit., pp 124-125.

15 Walker, op. cit., p 159.

16 J B Jacobs and K Potter Hate Crimes: Criminal Law o Identity Politics, Oxford University Press, New York, 1998, p 113.

17 ACLU News Wire Hate Speech on the Net, 10 September 1997 at < http://www.aclu.org/news/ w100997c.html>.

18 lbid.

19 S Smith 'There's such a thing as free speech' in R K Whillock and D Slayden (eds) Hate Speech, Sage, Thousand Oaks, CA, 1995, p 262.

20 M J Matsuda 'Public response to racist speech: considering the victim's story' in M J Matsuda, C R Lawrence III, R Delgado and K W Crenshaw (eds) Words That Wound: Critical Race Theory, Assaultive Speech, and the First Amendment, Westview Press, Boulder, 1993, p 49.

21 lbid., p 36.

22 Israel, op. cit., p 106.

23 A Harmon 'Technology: internet sale of Nazi books in Germany is assailed', New York Times, 9 Ausust 1999. Accessed at the Simon Weisenthal Webpage on 29 September $1999<$ http:// www.wiesenthal.com/itn/newyorktimes.html >.

24 'Hate blocker', USA Today, 17 December 1997, p 1D.

25 ADL-Anti-Defamation League, 1999. Retrieved from the world wide web at <http:// www.adl.org/frames/front_search.html $>$.

26 Israel, op. cit.

27 ADL-Anti-Defamation League 'Responding to Extremist Speech On-Line', 1999, at <http:// www.adl.org/issue_combating/10faq_extremism_online.html $>$.

28 lbid.

29 Israel, op. cit., pp 106-107.

30 ADL, op. cit., 1999.

31 Israel, op. cit., pp 106-107.

32 ADL, op. cit., 1999.

33 lbid.

34 lbid. 